\section{Homicides and socio-environmental determinants of health in Brazil: a systematic literature review}

\author{
Homicídios e determinantes socioambientais \\ da saúde no Brasil: uma revisão sistemática da \\ literatura
}

\section{Homicidios y determinantes socioambientales de la salud en Brasil: una revisión sistemática de la literatura}

Clovis Wanzinack 1

Marcos Claudio Signorelli 1

Clóvis Reis 2

\begin{abstract}
Brazil currently has the highest absolute number of homicides in the world, which results from a complex range of factors. This study aimed at understanding the associations between socio-environmental determinants of health (SDH) and homicides in Brazil through a systematic literature review. The review followed PRISMA guidelines, selecting quantitative and qualitative studies published in Portuguese, English, and Spanish carried out between 2002 and 2017, available in the PubMed, MEDLINE, LILACS, SciELO and BVS-BIREME databases. Two trilingual reviewers tracked studies independently by basing on the eligibility criteria. We critically assessed the selected studies with the Critical Appraisal Skills Programme (CASP) or the Checklist for Analytical Cross-Sectional Studies, depending on the study design. We considered 60 studies and grouped their SDH into categories to develop a narrative synthesis about each SDH. These categories were: territory; race/ethnicity; gender; age; social inequalities and economic factors; development; education; work and employment; drugs and trafficking; other SDH. We found some SDH were more associated with homicides, such as being young, black, male, of low education level, and also people who lived in places of high social inequality, such as urban suburbs and agricultural frontiers. Unemployment and drug trafficking, as well as intersections between various SDH were also prominent. Education seems to be a protective factor for homicide. Despite the limited capacity of interpretation due to the high range of methodological approaches, this review shows the importance of considering SDH and their intersections when developing homicide prevention policies.
\end{abstract}

Homicide; Violence; Social Determinants of Health

\author{
Correspondence \\ C. Wanzinack \\ Rua Jaguariaiva 512, Matinhos, PR 83260-000, Brasil. \\ cloviswa@gmail.com \\ 1 Universidade Federal do Paraná, Curitiba, Brasil. \\ 2 Universidade Regional de Blumenau, Blumenau, Brasil.
}




\section{Introduction}

According to the 49th World Health Assembly, held in 1996 1, violence is a public health issue that holds no consensus regarding the concepts, causes, and consequences of this complex subject. This study understood violence as a process of many historical causes that need to consider its cultural, economical, sociopolitical, environmental, and legal aspects in its analyses 2 .

Violence can manifest itself in different ways, including homicide, which is the pinnacle of violence, because it implies life annihilation. Homicides are the fourth main cause of death among people aged between 15 and 44 years old in the world 1. This study understood "homicide" based on the Brazilian Criminal Code, which defines it as the act of killing another person, be it due to malice, when there are intent and awareness of results, or due to guilt, negligence, or recklesness 3 . Homicide is one of the most important violence indicators, and the one that most clearly depicts the magnitude and severity of the situation 2 .

Estimates show that in 2012 approximately 475,000 people were victims of homicides worldwide, a rate of 6.7 homicides per 100,000 inhabitants 1. The rate in the American continent is 28.5/100,000, followed by Africa, with 10.7/100,000 1. These rates did not evenly distribute homicides considering genders, age groups, and socioeconomic factors. Men represent $82 \%$ of the victims, with estimated rates 4 times higher than women 1 . The highest rates of homicide worldwide are among men aged between 15 and 29 years old (18.2/100,000) 1 .

In Brazil, since the 1980s, there has been a significant growth in homicide-related deaths, particularly in urban environments, with young black males mostly being both aggressors and victims 4 . Recent studies point out to social inequalities as one of its main determinants 5,6. In 2005, the homicide rate in Brazil reached 27/100,000, being amongst the highest in the world 7. In 2012, Brazil accounted for approximately $10 \%$ of all homicides in the planet, thus being the country with the highest absolute number of homicides 1 .

This resulted from complex interactions between individual, relational, social, cultural, and environmental factors 8 . Aiming to understand the association of these factors with homicides is an important step for public health to prevent the issue and consequently other common violence manifestations

There is a growing need to understand socio-environmental conditions and their relations with the health-disease process. In 2005, World Health Organization (WHO) created the Commission on Social Determinants of Health 9 . Its goal was to raise awareness on the influence of social determinants on the health of individuals and groups, as well as the need for taking actions. Thus, understanding these determinants is the first step to elaborate policies and proposing health equality 9 .

Based on the aforementioned circumstances, the purpose of this study was to understand the relations between socio-environmental determinants of health (SDH) and homicides in Brazil by performing a systematic review of literature. This review was based on previous studies 8,9 that indicate that structural elements of social stratification determine and condition social positions and strata, sharing socioeconomic characteristics, such as education, income, gender, among others. These elements may lead to vulnerability exposure and health damages in the form of diseases and accidents, which may also lead to violence and homicides 9 .

Despite SDH not having a linear cause-and-effect relation to homicides, this article aimed to systematically explore what recent studies present on the main social, economical, and environmental factors linked to homicides in Brazil. The following questions guided this systematic review: (1) which SDH are associated with homicides in Brazil?; (2) which SDH were analyzed regarding their impact and association with homicides in Brazil?; (3) which SDH were analyzed as protective factors in preventing homicides in Brazil?

\section{Methodology}

The protocol for this systematic review was registered under the International Prospective Register of Systematic Reviews (PROSPERO) of the University of York, under number CRD42017073557. The systematic review was conducted and presented according to the Preferred Reporting Items for 
Systematic Reviews and Meta-Analysis (PRISMA) (Supplementary Material; http://cadernos.ensp. fiocruz.br/csp/public_site/arquivo/csp-0128-18appendix_3654.pdf).

\section{Research}

Research strategy included the following databases: PubMed Central, Medical Literature Analysis and Retrieval System Online (MEDLINE), Literature in the Health Sciences in Latin America and the Caribbean (LILACS), Scientific Electronic Library Online (SciELO), and Biblioteca Virtual em Saúde (BVS) by the Latin American and Caribbean Center on Health Sciences Information (BIREME). The boolean descriptors and operators used as a research strategy are in Box 1. Health science descriptors created by BIREME (http://decs.bvs.br/) have been adopted.

\section{Types of selected studies}

Studies of any kind of methodology (quantitative/qualitative) that analyzed homicides in Brazil and discussed their associations with SDH were included. Eligibility criteria for inclusion were: quantitative or qualitative studies on homicides in Brazil (1), whose methods included primary data collection or secondary data analysis (2), and were published between 2002 and June/2017 (3), in English, Spanish, or Portuguese (4). The year of 2002 was chosen as our starting point, because it was in that year that WHO has published the first main study on the impacts of violence on health 10.

Exclusion criteria were applied to studies that: did not approach homicides in Brazil (1), not included results or discussions about SDH and their association with homicides (2), presented reviews, opinion articles, case studies, editorials, policies, non-conventional literature, or conference abstracts ("grey literature") (3), were published in 2001 or before (4), and that focused on the psychological/ psychiatric state of perpetrators/victims instead of SDH (5), and on isolated/specific cases of mass homicides (serial killings, mass murders, or terrorism) (6).

\section{Article tracking and selection}

Two authors performed a double-blind review: a Ph.D. in Public Health and a doctorate candidate. Firstly, abstracts were independently tracked based on our research strategy (Box 1), and disagreements were solved with the support of a third author (Ph.D.). Causes for exclusion were registered for each article, as previously pointed out. Then, the studies that met the eligible criteria had its abstracts fully read (Figure 1).

\section{Critical appraisal}

There are several tools for assessing quality in systematic review. However, it is still a challenging process, considering there is no consensus about it. Being aware of its limitations, for this review, and following another systematic review 11 critical appraisal, we adopted the Critical Appraisal Skills Programme (CASP; http://www.casp-uk.net/casp-tools-checklists) checklist, which includes qualitative and quantitative study tools (randomized control trials, cohort, case-control, diagnostic studies, clinical prediction rule, and economical evaluation), following other recent systematic reviews 11,12,13. For cross-sectional studies, which are not covered by the CASP, we adopted the Checklist for Analytical Cross-Sectional Studies by the Joanna Briggs Institute (http://joannabriggs.or/research/ critical-apparisal-tools.html).

Initially, each study was classified according to its study design. Then, each of them was analyzed according to specific items that compose the aforementioned tools, including: study aims analysis, if the study design was appropriate and aligned with its aims, if data was measured in a valid and reliable way, rigorousness of analysis, application of results, among other items.

Eligible studies were classified using critical appraisal instruments according to the quality of evidence on SDH: very low (unclear) when the two screening questions (Section A of CASP) were not satisfied; low when the total score was < 50\%; moderate when total score was between $51 \%$ and $99 \%$; or high when total score $=100 \%$. 


\section{Box 1}

Adopted boolean descriptors and operators.

\begin{tabular}{|c|c|}
\hline Language & Descriptors and boolean operators \\
\hline Portuguese & 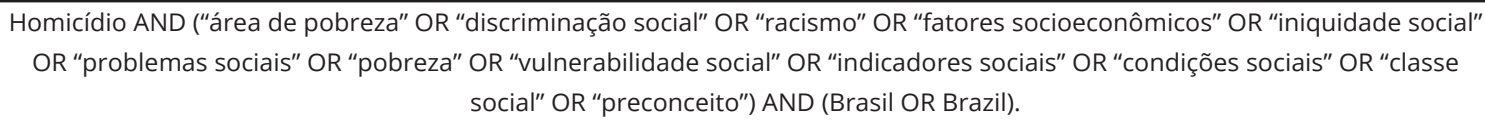 \\
\hline English & 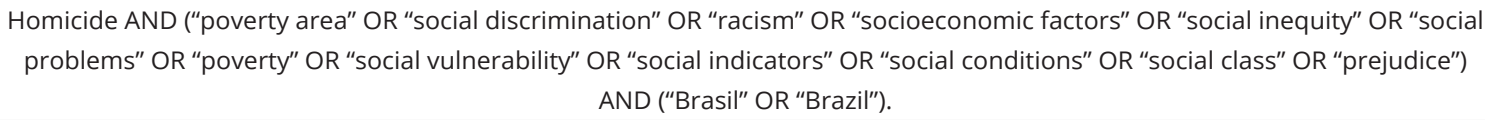 \\
\hline Using * & 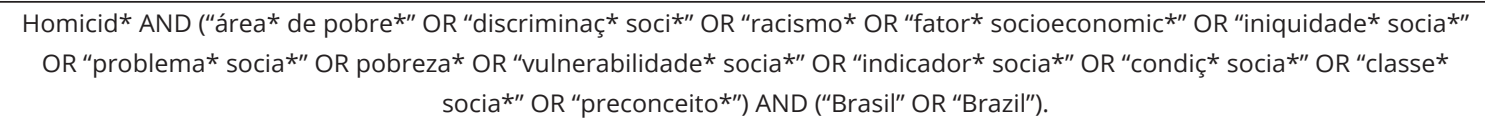 \\
\hline
\end{tabular}

Source: prepared by the authors, 2018.

\section{Figure 1}

Fluxogram showing the screening and selection process of articles, based on the PRISMA protocol.

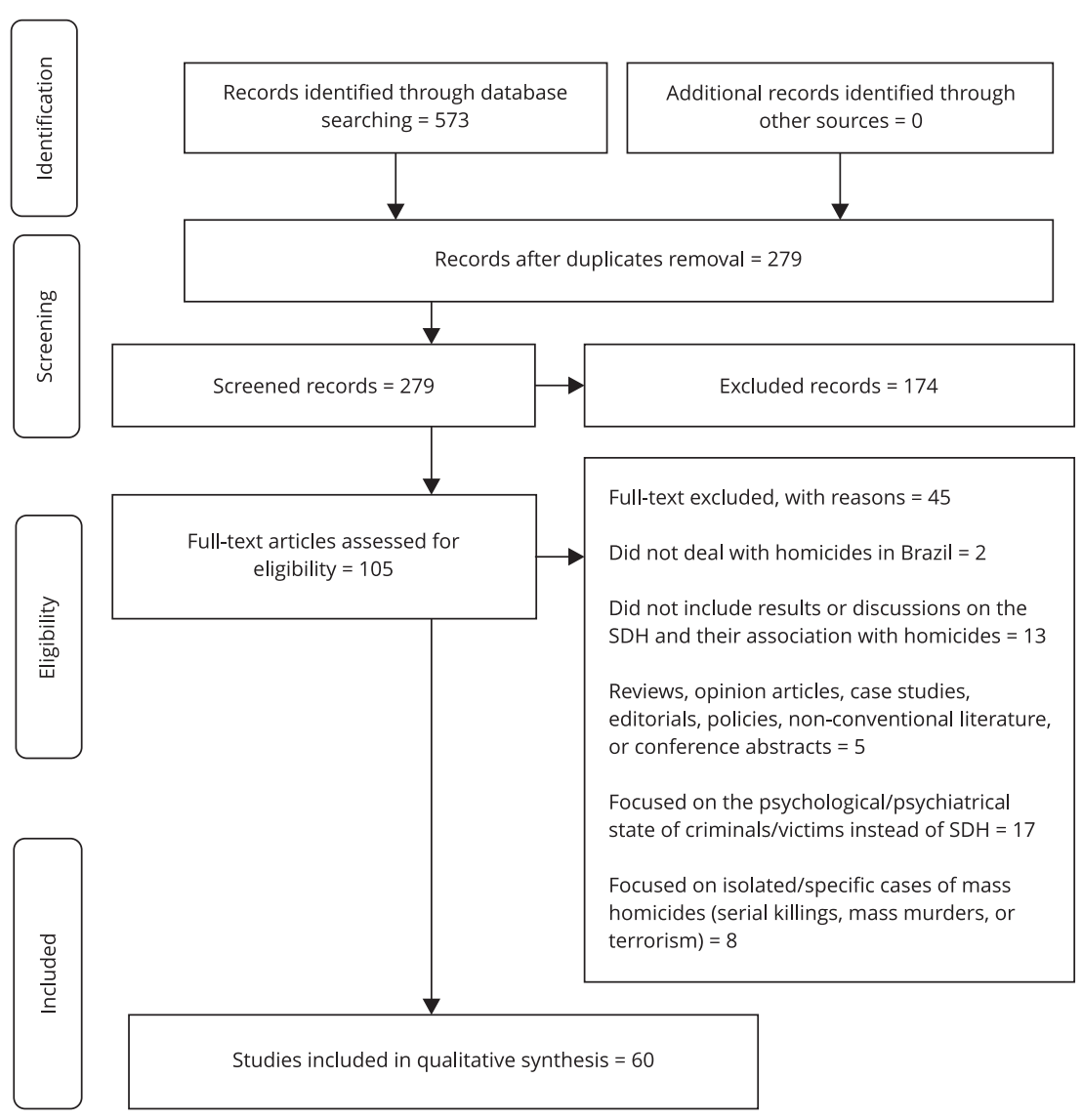

SDH: socio-environmental determinants of health.

Source: adapted from the PRISMA flowchart (http://prisma-statement.org/PRISMAStatement/FlowDiagram.apsx,

accessed on 04/Dec/2017). 


\section{Study management and storage}

Resulting articles were stored and managed using the online version of EndNote (http://www.end note.com), based on the following steps: (1) title and abstract reading of all the articles identified by the research strategy; (2) exclusion of duplicates and texts in other formats; (3) publication selection from 2002 onwards; (4) comparison between the two lists generated by independent researchers; (5) discussion involving these two researchers with the help of a third author, to reach consensus; (6) reading of full versions and critical analyses of the remaining articles.

\section{Data collection and synthesis strategy}

The collected data included title, authors, journal, year of publication, aims, study design, measures and outcomes, including quantitative and qualitative analysis of the SDH, which were grouped into 10 categories: territory; race/ethnicity; gender; age group; social inequalities and economical factors; development; education; work and employment; drugs and trafficking; other SDH.

Results were presented in a narrative synthesis 14 , categorizing its findings according to the most common SDH. A narrative analysis of each category was performed. As simply describing the studies is not enough to carry out a narrative synthesis, we adopted a textual approach that analyzes the associations implied in each study and the ones between studies, as well as an overall assessment of evidence rigorousness 14 . Following international guidelines for systematic review reporting, we also organized tables to provide a descriptive summary of the findings and explain study characteristics.

\section{Results}

After reading the full version of the 60 articles included in this review, we perfomed a narrative synthesis of results by categorizing the findings according to the following SDH: territory; race/ethnicity; gender; age group; social inequalities and economical factors; development; education; work and employment; drugs and trafficking; other SDH. Sections below will approach all SDH. The description of articles and its corresponding goals and SDH is in Table 1.

Out of 60 articles, 35 (58.33\%) were in Portuguese, 19 (31.67\%) in English, and 6 (10\%) in Spanish. A total of 15 articles (25\%) were published in international journals, whereas $45(75 \%)$ were published in Brazilian journals.

The study design essentially comprised observational studies, including ecological $(n=35)$, crosssectional $(n=3)$ and qualitative $(n=8)$ ones. A total of 17 studies did not define themselves as ecological, but their characteristics were based on ecological design. Some studies specified subtypes of ecological studies: "cross-sectional" $(n=7)$, "descriptive" $(n=6)$, "time-series" $(n=5)$, "exploratory" $(\mathrm{n}=1)$ and "longitudinal" $(\mathrm{n}=1)$.

Critical appraisal showed that most studies (47/60) satisfied all items from the appraisal tools, thus being considered of "high quality". Around 13 out of 60 were considered of "moderate quality" with scores varying from $60-99 \%$. Only four articles $15,16,17,18$ had the lowest CASP score of $60 \%(6 / 10)$ and all of them were qualitative studies, mainly lacking information about data collection or ethics clearance (these results were less considered in our narrative synthesis). Based on our appraisal, no studies were considered of low or very low quality.

\section{Territory}

Issues concerning territory were the most common out of all SDH. For this review, the adopted concept of territory was that of a human and social construct that could be obtained from geographic occupation, or as a symbolic appropriation based on the identity of cultural groups that create the environment where they live 19 .

Several studies included analyses of specific territories. Only 18 (30\%) dealt with studies on a national scale 5,7,15,16,17,18,20,21,22,23,24,25,26,27,28,29,30,31, while 13 studies (21.7\%) focused on homicides 


\section{Table 1}

Studies included in the systematic review according to year, author(s), title, goals, and socio-environmental determinants of health (SDH).

\begin{tabular}{|c|c|c|c|}
\hline Author (year) & Objective & SDH & Critical appraisal \\
\hline Perova \& Reynolds 20 (2017) & $\begin{array}{l}\text { This study estimates the effects of women's } \\
\text { police stations in Brazil on female homicides, } \\
\text { as a measure of the most severe form of } \\
\text { domestic violence. }\end{array}$ & $\begin{array}{l}\text { Territory, gender, age group, } \\
\text { social inequalities and } \\
\text { economic factors, education, } \\
\text { work and employment, } \\
\text { domestic violence. }\end{array}$ & High quality \\
\hline Tavares et al. 50 (2016) & $\begin{array}{l}\text { To analyze the spatial distribution of homicide } \\
\text { rates according to the social vulnerability index } \\
\text { (SVI) and the quality of urban life index (QUL) in } \\
\text { Betim, State of Minas Gerais, from } 2006 \\
\text { to } 2011 .\end{array}$ & $\begin{array}{l}\text { Territory, race/ethnicity, } \\
\text { gender, age group, social } \\
\text { inequalities and economic } \\
\text { factors, development, } \\
\text { education, work and } \\
\text { employment, drugs and } \\
\text { trafficking, access to firearms. }\end{array}$ & High quality \\
\hline Cardoso et al. 32 (2016) & $\begin{array}{l}\text { To analyze the evolution of homicide rates } \\
\text { based on the following categories: murder, } \\
\text { larceny, bodily harm followed by death, } \\
\text { homicide for resistance to police resulting in } \\
\text { death, killed policemen, missing people and } \\
\text { dead bodies found in the state and city of Rio } \\
\text { de Janeiro and in Integrated Public } \\
\text { Security Area. }\end{array}$ & $\begin{array}{l}\text { Territory, drugs } \\
\text { and trafficking. }\end{array}$ & High quality \\
\hline Cerqueira \& Soares 21 (2016) & $\begin{array}{l}\text { This study estimates the health dimension } \\
\text { of the welfare cost of homicides in Brazil by } \\
\text { considering age, gender, educational, and } \\
\text { regional heterogeneities. }\end{array}$ & $\begin{array}{l}\text { Gender, age group, social } \\
\text { inequalities and economic } \\
\text { factors, education, work } \\
\text { and employment. }\end{array}$ & High quality \\
\hline Trindade et al. 42 (2015) & $\begin{array}{l}\text { To describe the profile of victims and gunshot } \\
\text { assaults which resulted in death. }\end{array}$ & $\begin{array}{l}\text { Gender, age group, social } \\
\text { inequalities and economic } \\
\text { factors, education, work } \\
\text { and employment, drugs and } \\
\text { trafficking, access to firearms. }\end{array}$ & Moderate quality \\
\hline Souza et al. 33 (2015) & $\begin{array}{l}\text { This study analyzed the relationships between } \\
\text { the various economic processes of territorial } \\
\text { occupation in the Amazon and the spatial } \\
\text { diffusion of homicidal violence through the } \\
\text { configuration of production networks, as well } \\
\text { as social movements and merchandise. }\end{array}$ & $\begin{array}{c}\text { Territory, social inequalities } \\
\text { and economic factors, } \\
\text { development. }\end{array}$ & High quality \\
\hline Garcia et al. 22 (2015) & $\begin{array}{l}\text { The objective of the study was to estimate the } \\
\text { corrected femicide rates and to describe the } \\
\text { characteristics of these deaths in Brazil during } \\
\text { the } 2009-2011 \text { triennium. }\end{array}$ & $\begin{array}{l}\text { Race/ethnicity, gender, age } \\
\text { group, social inequalities } \\
\text { and economic factors, } \\
\text { development, education, work } \\
\text { and employment, drugs and } \\
\text { trafficking, domestic violence. }\end{array}$ & High quality \\
\hline Rojas Cabrera 43 (2015) & $\begin{array}{l}\text { The scope of this paper is to analyze and } \\
\text { compare the evolution of deaths from violent } \\
\text { causes among adolescents and young adults } \\
\text { in the cities of Córdoba (Argentina) and Porto } \\
\text { Alegre (Brazil). }\end{array}$ & $\begin{array}{l}\text { Gender, age group, drugs } \\
\text { and trafficking. }\end{array}$ & High quality \\
\hline
\end{tabular}

(continues) 
Table 1 (continued)

\begin{tabular}{|c|c|c|c|}
\hline Author (year) & Objective & SDH & Critical appraisal \\
\hline Pereira et al. 45 (2015) & $\begin{array}{l}\text { The purpose was to investigate the } \\
\text { determinants of homicide in Recife, Brazil, } \\
\text { based on the social disorganization theory. }\end{array}$ & $\begin{array}{l}\text { Territory, social inequalities } \\
\text { and economic factors, } \\
\text { education, work and } \\
\text { employment, sanitation. } \\
\text { gender, age group, drugs and } \\
\text { trafficking. }\end{array}$ & High quality \\
\hline Molinatti \& Acosta 23 (2015) & $\begin{array}{l}\text { It describes deaths by assault trends in women } \\
\text { from Argentina, Brazil, Chile, Colombia, and } \\
\text { Mexico, between } 2001 \text { and } 2011 .\end{array}$ & $\begin{array}{l}\text { Gender, age group, social } \\
\text { inequalities and economic } \\
\text { factors, development, } \\
\text { education. }\end{array}$ & High quality \\
\hline Araújo et al. 52 (2014) & $\begin{array}{c}\text { This study describes the spatial distribution of } \\
\text { mortality from external causes according to } \\
\text { socioeconomic level. }\end{array}$ & $\begin{array}{l}\text { Territory, social inequalities } \\
\text { and economic factors. }\end{array}$ & Moderate quality \\
\hline Sousa et al. 35 (2014) & $\begin{array}{l}\text { This study aims to analyze the possible } \\
\text { relationship between social determinants } \\
\text { and homicide mortality in Fortaleza (Ceará } \\
\text { State), Brazil. }\end{array}$ & $\begin{array}{l}\text { Gender, age group, social } \\
\text { inequalities and economic } \\
\text { factors, education, work } \\
\text { and employment, drugs and } \\
\text { trafficking, sanitation. }\end{array}$ & Moderate quality \\
\hline Barcellos \& Zaluar 51 (2014) & $\begin{array}{l}\text { To evaluate the risk of homicide in Rio de } \\
\text { Janeiro's favelas, taking into account the } \\
\text { territorial disputes taking place in the city. }\end{array}$ & $\begin{array}{l}\text { Territory, drugs and } \\
\text { trafficking. }\end{array}$ & Moderate quality \\
\hline Souza et al. 24 (2014) & $\begin{array}{c}\text { To carry out a study on the association } \\
\text { between socioeconomic and demographic } \\
\text { factors and homicides from general } \\
\text { population, in the state of Bahia, in } 2009 \text {. }\end{array}$ & $\begin{array}{l}\text { Territory, gender, age } \\
\text { group, social inequalities } \\
\text { and economic factors, } \\
\text { development, education, work } \\
\text { and employment. }\end{array}$ & Moderate quality \\
\hline Bando \& Lester 72 (2014) & $\begin{array}{c}\text { The objective was to evaluate correlations } \\
\text { between suicide, homicide and } \\
\text { sociodemographic variables by an } \\
\text { ecological study. }\end{array}$ & $\begin{array}{l}\text { Race/ethnicity, gender, age } \\
\text { group, social inequalities and } \\
\text { economic factors, education, } \\
\text { work and employment, drugs } \\
\text { and trafficking, suicide. }\end{array}$ & Moderate quality \\
\hline Souza et al. 70 (2014) & $\begin{array}{l}\text { To analyze the spatial distribution of homicide } \\
\text { mortality in the state of Bahia, } \\
\text { Northeastern Brazil. }\end{array}$ & $\begin{array}{l}\text { Territory, gender, age group, } \\
\text { social inequalities and } \\
\text { economic factors, drugs and } \\
\text { trafficking. }\end{array}$ & High quality \\
\hline Leites et al. 36 (2014) & $\begin{array}{c}\text { This study aimed to assess the female } \\
\text { homicide rate due to aggression in Rio Grande } \\
\text { do Sul, Brazil, using this as a "proxy" } \\
\text { of femicide. }\end{array}$ & $\begin{array}{l}\text { Gender, social inequalities } \\
\text { and economic factors, drugs } \\
\text { and trafficking. }\end{array}$ & High quality \\
\hline Chiavegatto Filho et al. 25 (2014) & $\begin{array}{c}\text { This study calculated life expectancy at birth } \\
\text { for white, black, and mixed race people from } \\
\text { Brazil, and decomposed the differences among } \\
\text { them by death causes. }\end{array}$ & $\begin{array}{l}\text { Race/ethnicity, gender, social } \\
\text { inequalities and economic } \\
\text { factors, education. }\end{array}$ & High quality \\
\hline Salama 15 (2013) & $\begin{array}{l}\text { This study presented a general panorama of } \\
\text { violence and homicides in Latin America, also } \\
\text { including a discussion about the } \\
\text { Brazilian context. }\end{array}$ & $\begin{array}{l}\text { Territory, gender, age } \\
\text { group, social inequalities } \\
\text { and economic factors, } \\
\text { development, education, } \\
\text { drugs and trafficking. }\end{array}$ & Moderate quality \\
\hline
\end{tabular}

(continues) 
Table 1 (continued)

\section{Author (year)}

Mansano et al. 37 (2013)

Silva et al. 46 (2013)

Alves et al. 47 (2013)

Chiavegatto Filho et al. 53 (2012)

Peres et al. 54 (2012)

Briceño-León 16 (2012)

Nery et al. 55 (2012)

Minayo \& Constantino 62 (2012)

Gomez-Lievano et al. 26 (2012)

Objective

SDH

Critical appraisal

The aim of this study was to describe the extent and temporal trends of the homicide mortality rate (HMR) in male individuals aged 10-24 according to the characteristics of the municipalities from the states of Paraná and Santa Catarina, between 2001 and 2010.

This study investigated the epidemiological profile of female homicide victims from Recife,

Pernambuco State, Northeast Brazil.

To analyze deaths from external causes and undefined causes in women of childbearing age that occurred during pregnancy and early postpartum.

To analyze cause-specific mortality rates according to the relative income hypothesis.

The scope of this study was to analyze the association between homicides and public security indicators in São Paulo between 1996 and 2008, after monitoring the unemployment

rate and the youth proportion in the population.

This study analyzes and compares the changes occurred in Colombia, Venezuela and Brazil in the first decade of the twentyfirst century, where the homicide rate has decreased, increased and remained the same, respectively.

To identify the existence of spatial and temporal patterns in the occurrence of intentional homicides in the municipality of São Paulo, Brazil, and to discuss the analytical value of considering such patterns $t$ when designing studies that address the dynamics and factors associated with homicide incidence.

This study analyzed four cities regarding homicide rates, namely two Brazilian and two Argentinian cities. In each country, it studied a city with high homicide rates and another with low rates over the same three-year period.

This study aims at building a self-consistent statistical framework that characterizes the joint probability distributions of urban indicators and city population sizes across an urban system.
Territory, gender, age group, social inequalities and economic factors, education, work and employment, drugs and trafficking.

Race/ethnicity, gender, age

group, social inequalities and economic factors, education, drugs and trafficking.

Race/ethnicity, gender, age range, access to firearms.

Social inequalities and economic factors, development, work and employment.

Work and employment.

Race/ethnicity, social inequalities and economic factors, development, education, work and employment, drugs and trafficking.

Social inequalities and economic factors.

Territory, age group, social inequalities and economic factors, development, education, work and employment, drugs and trafficking.

Territory, social inequalities and economic factors.
High quality

High quality

High quality

High quality

High quality

Moderate quality

High quality

High quality

High quality 
Table 1 (continued)

\section{Author (year)}

Duarte et al. 5 (2012)

Belon et al. 69 (2012)

Andrade et al. 27 (2012)

Andrade et al. 38 (2011)

Peres et al. 56 (2011)

Meneghel \& Hirakata 28 (2011)

Reichenheim et al. 29 (2011)

Soares Filho 30 (2011)

Silva et al. 48 (2011)

Viana et al. 63 (2011)

Objective

SDH

Critical appraisal

The aim of this study was to assess the homicide mortality risk (HMR) among males aged 20-39, and its association with selected sociodemographic characteristics of the Brazilian municipalities.

The objective of this study was to identify the magnitude of social differences in mortality among adult residents of a city of one million people in Southeastern Brazil between 2004 and 2008.

To analyze the spatial distribution of juvenile homicide mortality for males in the city of Foz do Iguaçu (state of Paraná), located in the triple-border area between Brazil, Paraguay, and Argentina, between 2000 and 2007.

The objective of this study was to verify mortality rates due to homicides and legal interventions among young men in the State of Paraná, Brazil, and to identify correlated municipal characteristics.

It describes homicide mortality in the municipality of São Paulo according to the type of weapon, sex, race or skin color, age, and areas of socioeconomic inequalities, between 1996 and 2008.

It assesses female homicide rates due to aggression according to sociodemographic and health indicators.

The aim of this paper was to describe the impact and challenges of violence in Brazil, including homicides.

It describes the temporal patterns of mortality by homicide in Brazil, analyzing the variables race/skin color, gender and education.

This study aimed to calculate the potential years of life lost by female homicide victims in Recife, Pernambuco State, Brazil, in 2003-2007.

Analysis to assess the evolution of sociospatial inequalities in mortality due to external causes and homicides in Salvador, state of Bahia, Brazil, between 2000 and 2006.
Gender, age group, social inequalities and economic factors, inequality, education, work and employment, drugs and trafficking.

Gender, age group, social inequalities and economic factors, inequality.

Territory, race/ethnicity, gender, age group, social inequalities and economic

factors, education, work and employment.

Gender, age group, social inequalities and economic factors, development, work and employment, drugs and trafficking.

Age range, social inequalities and economic factors, development, drugs and trafficking.

Race/ethnicity, gender, social inequalities and economic

factors, education, work and employment.

Territory, race/ethnicity, gender, age group, education, drugs and trafficking, access to firearms.

Race/ethnicity, gender, social inequalities and economic factors, education, work and employment.

Race/ethnicity, gender, age group, social inequalities and economic factors, development, education, work and employment, access to firearms.

Territory, gender, social inequalities and economic factors, development, education, work and employment, drugs and trafficking.
High quality

High quality

High quality

High quality

High quality

High quality

High quality

High quality

High quality

High quality 
Table 1 (continued)

\begin{tabular}{|c|c|}
\hline Author (year) & Objective \\
\hline Peres et al. 57 (2011) & $\begin{array}{l}\text { The aim of this study is to describe the } \\
\text { trend of homicide mortality rate (HMR), } \\
\text { sociodemographic indicators, and the } \\
\text { investment in social and public security, and } \\
\text { to analyze the correlation between HMR and } \\
\text { independent variables in the municipality of } \\
\text { São Paulo between } 1996 \text { and } 2008 \text {. }\end{array}$ \\
\hline Araújo et al. 73 (2010) & $\begin{array}{l}\text { To evaluate the relative contribution of } \\
\text { race/skin color to the spatial distribution of } \\
\text { mortality by homicide in Salvador, state of } \\
\text { Bahia, Brazil, in the period 1998-2003. }\end{array}$ \\
\hline
\end{tabular}

Barcellos et al. 34 (2010)

Lotufo \& Beseñor 58 (2009)

Bastos et al. 65 (2009)

Nadanovsky et al. 7 (2009)

Araújo et al. 64 (2009)

Nadanovsky \& Cunha-Cruz 68 (2009)

Nadanovsky 39 (2009)

Minamisava et al. 66 (2009)

Briceño-León et al. 17 (2008)
This study examines the spatial distribution of three major health threats in the Brazilian Amazon region that may undergo changes through highway construction.

To analyze the relations between male homicide rates and income inequality in the city of São Paulo, Brazil, between 1996-2007.

To analyze the socioeconomic background and its relationship with spatial distribution of mortality due to violence in the city of Vitória, state of Espírito Santo, Brazil.

To assess a new impunity index and variables that have been found to predict variation in homicide rates in other geographical levels as predictive of state-level homicide rates in Brazil.

The aim of this study was to analyze differentials in mortality by external causes according to race/skin color, estimating potential years of life lost.

The objective of this study was to investigate the association between income inequality and imprisonment with homicide rates among Developed (OECD), South and Central American countries.

To describe the reduction in the homicide rate in the state of São Paulo between 1996 and 2005, verifying its correlations with the increase in the incarceration rate.

This study analyzed the spatial distribution and potential clusters of risk for intentional and unintentional deaths among youths aged between 15 and 24 years in Goiânia, a newly

urbanized city in State of Goiás, Brazil.

This study reviewed epidemiological data on violence and homicide in Latin America, discussing its unequal distribution between the Latin American countries in the context of a sociological framework as well as from a public

\section{health perspective.}

SDH

Critical appraisal

Age range, social inequalities and economic factors, development, work and employment, drugs and trafficking.

Race/ethnicity, gender, age group, social inequalities and economic factors, education, work and employment, drugs and trafficking.

Development, drugs and trafficking.

Territory, gender, age group, social inequalities and economic factors, drugs and trafficking.

Territory, race/ethnicity, gender, age group, social inequalities and economic factors.

Gender, age group, social inequalities and economic factors, development, education.

Race/ethnicity, gender, age group, social inequalities and economic factors.

Age range, social inequalities and economic factors, education, work and employment.

Social inequalities and economic factors, work and employment, imprisonment.

Age group, social inequalities and economic factors, development.

Gender, age group, social inequalities and economic factors, education.
High quality

High quality

High quality

High quality

High quality

High quality

High quality

High quality

High quality

High quality

Moderate quality

(continues) 
Table 1 (continued)

\section{Author (year)}

Cardona et al. 31 (2008)

Barata et al. 59 (2008)

Peres et al. 60 (2008)

Santos et al. 49 (2007)

Santos et al. 44 (2006)

Gawryszewski \& Costa 6 (2005)

Lima et al. 41 (2005)

Caiaffa et al. 67 (2005)

Batista 40 (2005)

Kilsztajn et al. 61 (2005)

Phebo \& Moura 18 (2005)

\section{Objective}

This article has the objective of contributing to studies on mortality from violent causes in Latin America through a comparative analysis

of recent patterns and trends in deaths

from external causes in three regional urban contexts from Argentina, Brazil and Colombia.

This study aimed to identify patterns in the occurrence of homicides considering the characteristics of aggressors, victims and the circumstances that motivated the aggression, according to life condition strata.

To analyze the association between police violence and homicide mortality rates by considering the effect of contextual variables. The study aimed to characterize the mortality pattern of black and white adult women living in Recife, state of Pernambuco, between 2001 and 2003.

To analyze the spatial distribution of homicide victims by place of residence in Porto Alegre, capital of the state of Rio Grande do Sul, Brazil to identify and understand the sociospatial context of 1996.

The proposal of this ecological study was to test the association between homicide rates, and some health and socioeconomic indicators in the city of São Paulo.

To investigate the association between homicide rates and socioeconomic variables by considering the spatial site of the indicators, in the state of Pernambuco, between 1995 and 1998.

This study aims to determine spatial patterns of mortality and morbidity for five health problems in an urban area from Belo Horizonte, state of Minas Gerais: homicides, adolescent pregnancy, asthma hospitalization, and two vector-borne diseases, dengue, and visceral leishmaniasis.

This article analyzes the mortality profile of black and white men as registered in the death certificates emitted by the state of São Paulo in 1999.

To analyze the homicide rate by racial/ethnic origin in the Greater Metropolitan area of São Paulo, Brazil, considering schooling, gender, and age.

To present the main aspects of an approach to urban violence among children and adolescents and to point out the social and educational role of pediatricians.
SDH

Critical appraisal

Gender, age, drugs and

High quality trafficking, access to firearms.

Race/ethnicity, gender, age group, social inequalities and economic factors, work and employment, drugs and trafficking, access to firearms.

Social inequalities and economic factors, education,

work and employment.

Race/ethnicity, gender, age group, social inequalities and economic factors, education, domestic violence.

Social inequalities and economic factors, education.

Gender, age group, social inequalities and economic

factors, education, work and employment.

Gender, age group, social inequalities and economic factors, education, work and employment.

Territory, social inequalities and economic factors.

Race/ethnicity, gender, age

Moderate quality group.

Race/ethnicity, gender, social Moderate quality inequalities and economic factors, education.

Race/ethnicity, gender, age Moderate quality
High quality

Moderate quality

High quality

High quality

High quality

High quality

High quality economic factors, access to firearms.

Source: organized by the authors, 2018. 
in specific Brazilian states, including Rio de Janeiro 32, Amazonas 33,34, Bahia 35, Rio Grande do Sul 36, Paraná 37,38, Santa Catarina 37, Mato Grosso 34, São Paulo 39,40, and Pernambuco 41.

Regarding municipalities, 31 studies (51.7\%) analyzed cities and/or metropolitan areas in Maceió (Alagoas State) 42, Porto Alegre (Rio Grande do Sul State) 43,44, Recife (Pernambuco State) 45,46,47,48,49, Fortaleza (Ceará State) 35, Betim (Minas Gerais State) 50, Rio de Janeiro 32,51, Feira de Santana (Bahia State) 52, São Paulo 6,53,54,55,56,57,58,59,60,61, Jaraguá do Sul (Santa Catarina State) 62, Paulista (Pernambuco State) 62, Salvador (Bahia State) 57,63,64, Vitória (Espirito Santo State) 65, Goiânia (Goiás State) 66, and Belo Horizonte (Minas Gerais State) 67.

There were also other territorial approaches, such as the role of Brazil in the Latin American context $15,16,17,23,26,27,31,43,62,68$, or the context of specific Brazilian regions, such as the Amazon 33,34, the Brazilian Southeast 69 or the Brazilian South 68.

Studying the territory is essential to understand the dynamics of homicides. Studies suggested a higher rate of homicides in areas/territories of higher social vulnerability and lower quality of life in urban environments $5,6,7,29,31,33,42,50$. Social inequality seems to be one of the most popular justifications for the homicide epidemic (even more than poverty in absolute terms), being linked to urbanization issues and high populational growth 5 . However, it is not possible to associate homicides only with poverty, because rich cities and regions have also shown high homicide rates 38,48,65. Instead, we should reflect on how urbanization and the reckless growth of cities/regions can cause social inequality and, consequently, be more closely connected to homicides.

For example, one of the studies focused on Maceió 42 , which is considered one of the capitals with the highest homicide rates. However, this study showed that despite homicides happening in all of its neighborhoods, the distribution of these occurrences is not even. Regarding territory, the research showed different regional patterns of armed aggression, hence indicating that there are regions where the population is more vulnerable to homicides, which points out to the need of considering urban inequality.

Another study about homicides and youth in Santa Catarina and Paraná 37 showed an increase in homicide rates in Brazilian borders with Paraguay and cities close to highways that connect the Paraguayan border with capitals and big cities in the South and Southeast regions of Brazil. It also showed that cities in the Brazil-Argentina were at a lower risk when compared to those from other areas. This situation can be explained by the association between violence and the trafficking of drugs, firearms, and other products in the border with Paraguay, in addition to relevant factors such as social inequity and the lack of special government policies for this region 37.

The North, Northeast, and Central regions of Brazil are agricultural frontier areas prone to severe land tenure-related conflicts, with the highest rates of deaths due to homicide, whereas the South and Southeast regions, which are more densely populated and developed, showed the lowest rates 29 .

\section{Race/ethnicity}

The association between homicides and ethnic-racial issues is well documented in Brazil, showing that blacks and "mixed" race people represent most of homicide victims, which prompted the coining of the expression "genocide of the black population in Brazil" 40,49,64. A total of 20 articles (33.3\%) discussed ethnic-racial issues and their association with homicides.

A descriptive study carried out in Salvador between 1998 and 2003 with a sample of 9,626 deaths due to external causes showed that black individuals die earlier and lose 12.2 times more potential years of life because of homicides when compared to white individuals 64 .

A time series for homicides in Brazil from 2000 to 2009 showed that the black population represented $69 \%$ of homicide victims for this time period 30 . Blacks have a higher risk of death from homicide than white people, regardless of their level of education. Relative homicide risk increases in the black population and decreases in the white population, which suggests an increase in inequalities 30.

This increase in homicides is due to the social and economical inequalities between regions, populations, rich and poor individuals, as well as between racial/ethnic groups 44,49,57. This is directly associated with low income and education, and can also be associated with other types of violence, such as racism and discrimination 29,48,64. A research on São Paulo youth map 59 showed that outskirt areas, which are poorer and have the worse living conditions, are also the ones with the highest concentration 
of black population $59,61,64$. Therefore, ethnicity is an important indicator of social inequality, pointing to higher rates of death by homicide, as shown by various research 65 .

Nevertheless, it is worth to highlight that race/ethnicity is commonly linked to other SDH, which increases exposure to homicides. Skin color is a social marker of difference and racism is present in several levels in the Brazilian society. However, we outline the importance of reflecting on the SDH as a group of interconnected factors. In other words, whithout denying racism, what exposes people to homicides is not solely race/ethnicity, but racism alongside the socioeconomic context in which its victims live in $30,40,64$.

A study 30 with robust data indicated that mortality of the black population stems from low levels of income and education, while also possibly stemming from racism and discrimination, therefore inferring that these factors influence homicides in this population. Another challenging fact is the data that shows an increase of $28.6 \%$ in black victims of homicides between 2000 and 2009, whereas the number of white victims decreased by $24.5 \%$ in the same period 30 .

\section{Gender}

There is a huge difference in homicides rates concerning gender. Even after accounting for the studies' methodological variability, men were unanimously more susceptible to homicides than women, possibly up to 10 times more ${ }^{50}$. A total of 40 articles (66.67\%) discussed the association between gender and homicides.

Between 2000 and 2009, homicide rates for white men were 10 times higher than for white women, whereas for black men it were three times higher than for black women ${ }^{30}$. Lifestyle, habits and social behavior, urbanization, and socioeconomic level can socially determine differences in homicide rates $17,36,40,65$.

Despite the number of women victims of homicide being lower than for men, one should not dismiss this issue, as there is need to consider the number of gender asymmetries. Whereas men are more prone to homicides on the streets, women are more killed inside their own home, in an allegedly safer environment $36,48,49$. Women homicides are greatly associated with intimate partner violence. Estimates show that $35 \%$ of women worldwide have already suffered from physical or sexual violence by intimate partners or sexual violence by non-partners 22 .

Many studies 20,22,28,36,48,49 call attention to femicide in Brazil, which consists of gender-based homicides from which women are victims just for being women 28,36. Between 2003 to 2007, approximately 20,000 women died from femicide in Brazil, mostly young, single, of low education level 28. Statistics suggest that woman homicide happens every two hours in Brazil, the 12th country in the world ranking of women homicides 29 .

Unequal gender relations culminate in men's dominance over the body and life of their partners, as an expression of male hegemony, aggressiveness, and macho-culture 28,36,48. Macho-culture and misogyny are the results of a patriarchal system that predispose violence and feminicide 36 . Moreover, other SDH intersect gender issues and exponentiate the problem, such as the use of legal drugs (alcohol) and illegal drugs by the perpetrator 34 , as well as race/ethnicity issues (homicides are more common among black women than white women) and socioeconomic factors (exposure of poor women is more significant than in rich women) $30,46,57,61$.

\section{Age group}

Homicides in Brazil are the main cause of premature death, directly affecting the lives of young people 32,43,56,63. Out of 60 articles, $39(65 \%)$ discussed age group issues and their association with homicides.

Studies show that violence is a factor that leads to early death of young people, preventing them from enjoying economical development in the country in the last decade 32 . They also indicate that young men aged between 15 and 39 years old are the main victims and perpetrators of homicides, mostly due to social inequalities 42,70 . Much of this results from the exclusion from formal education, lack of employment and of future prospects. As homicides do not occur evenly among distinct ages, the age group from 15 to 39 years is the most vulnerable one. However, age groups should 
not be analyzed separately from other SDH. In addition to age, economically unfavorable environments can impact individuals and contribute to violence, poverty, and social exclusion, leading to homicides $5,17,21,24,37,42$.

\section{Social inequalities and economical factors}

Homicides have a strong social meaning, not only because they take away life, which is a right of every citizen, but also because they are a reflex of the problems faced by our society, such as inequalities, impunity, corruption, among others 50 . Out of 60 articles, most of them ( $n=51$ or $85 \%$ ) discussed social inequalities or economical factors and its association with homicides.

Studies showed a strong relation between homicides and quality of life issues, highlighting their direct association with social inequity $27,41,58$ and youth unemployment 17 . Unfavorable socioeconomic conditions may lead to social and health inequalities. Social disadvantages play a prominent role in homicide rates $37,41,47,62,66$. People that live in poorer areas with limited access to public facilities are more prone to higher homicide rates $35,38,52,69,70$.

As population grows, income inequality becomes an important factor for homicides 38 . Social inequality is more than economical inequality; poverty is not the problem itself, but the so-called relative poverty, which prevent some people who live under unfavorable conditions from having specific opportunities $18,30,38$.

A study on social inequality showed that groups from cities with more income inequality (i.e. a higher Gini index) have higher homicide rates 37 . For most social indicators, there was a lower risk of homicide for groups from cities with more favorable conditions, with lower unemployment and illiteracy rates and fewer people and children living in extreme poverty 37.

Studies $18,23,24,35,45,51,60$ indicated that income or wealth alone is not enough to explain homicides, neither to adopt interpretations in which the socioeconomic environment determines the behavior of an individual. Poverty by itself cannot explain the high risk of homicides for vulnerable groups. One should highlight that issues concerning social inequality, injustice, exclusion, populational growth, inefficient government, altogether, seem to be responsible for the rise of homicides in Brazil 18,23,24,35,45,51,60.

However, income seems to be a protective factor against homicides. A study on the determinants of homicides in Bahia showed a direct association between the amount of people who received Brazilian Income Transfer Program (Programa Bolsa Família) grants and homicides, indicating that areas that receive more help from the government are the ones with more social protection resources 24 . Another study from the state of São Paulo correlates the homicide mortality coefficient and independent variables, pointing out to how this coefficient increases as income decreases 60 . When measuring income as a natural logarithm, there was an increase of $1 \%$ in income results in an expected decrease of 0.695 in homicides, showing how directly and significantly income impacts homicides 45 .

\section{Development}

The concept of development is complex, and we do not aim at discussing it. We wanted to point out studies on the association between development and homicides, accounting for 18 studies (30\%).

The stagnation of Brazilian economy in the 1980s hindered income inequality, which has been associated with an accelerated urbanization process since previous decades. Most of the population moved from rural areas to city suburbs, without having access to adequate infrastructure services. Consequently, the growth of youth population since the 1960s and the ensuing high rates of unemployment and informal jobs (mainly for people with low levels of education) also contributed to the increasing homicide rates 29,57 .

The lack of decent urban development, mainly in the suburbs of large cities, has been contributing to less policing, worse public lighting, and insufficient public transportation, thus further exposing people who live in these areas to violence and homicides 6 . Therefore, this need for local development and decent public equipment can contribute to organized crime settling (particularly regarding drug and firearm trafficking) where the government is less present, thus leading to more homicides 6 . 


\section{Education}

Social inequality and institutionality levels are variables that determine a higher prevalence of homicides $25,43,53$. Out of 60 studies, most of them 33 (55\%) dealt with education-related issues as potential determinants of homicide.

People with a lower level of education represent the largest group of homicide victims, regardless of race/skin color, when compared to victims with a higher level of education 29,35,49,64. Education can significantly reduce the risk of homicide, being considered an important protective factor 29,35,39,54. However, once again, it is not possible to analyze education level separately, as a low level of education can stem from a low socioeconomic level, and consequently to higher exposure to violence and homicides 6,24,30,48,57,60. A highly educated population presents lower homicide rates and other criminal activities, as it ensures better job and income prospects, while also giving young people an occupation and preventing them from criminal activity 20,45,46,48.

A study on homicides in the state of São Paulo 60 suggested a correlation between the homicide mortality coefficient and independent variables, pointing out to how this coefficient increases as education and income levels decrease. Additionally, the increase in the amount of illiterate people with more than 15 years of age is connected to higher coefficients of death due to homicide.

\section{Work and employment}

SDH also includes work and employment, but its results were not very conclusive; studies usually focus on discussing income rather than discussing work and employment themselves. For example, a study stated that an increase in the income logarithm results in a decrease of 17.92 in the homicide rate 6. Different studies showed that intersections of different variables, including (un)employment, are decisive for homicide mortality, such as intersections with income (bad distribution) and low levels of education 35. Another potential determinant was social disorganization theory as it correlates the lack of employment and social problems, which may lead people to crime 35,50. Another study suggested that, among Brazilian states, unemployment is negatively associated with suicide, but positively with homicide 34 .

Regarding work and intersections with other SDH, homicides seem to be more common among disadvantaged groups from urban territories with unfavorable employment, income, education, and housing issues 48 . Income inequality, differences in the access for distinct populational groups, and poor social resources can determine the degree of violence in each region 18,19,65. On the other hand, a higher number of formal job opportunities prevents youth from crime, especially trafficking, resulting in the decrease of homicide rates 56.

\section{Drugs and trafficking}

In Brazil, there is a direct association between homicides and drug/firearm trafficking, a powerful economical sector which employs coercion, threats, and executions as land control mechanisms and disputes over drug-selling locations 50. A total of 26 studies (43.3\%) approached drugs and trafficking as potential homicide-related $\mathrm{SDH}$.

Drug trafficking is responsible for a high number of homicides caused by the corroding penal code established by traffic, which has led young family members from poor neighbourhoods, to death; the bloody competition between drug dealers over profit; and conflicts with the police, including sometimes corrupt policemen that demand a share of their profit 61.

Nevertheless, Brazil cannot be analyzed separately from the Latin American context, particularly regarding this SDH. Latin America presents the highest homicide rates 1 and is infamous for being as an illicit drug manufacturer involved in international trafficking. It is important to understand how neighboring countries have been studying and dealing with this issue to promote joint actions. A Colombian study analyzed the extraordinarily high homicide rates in the country and was able to identify three structural causes for it: inequality, impunity, and intolerance, as well as three transition processes, namely drug trafficking, internal armed conflicts, and the introduction and development of a neoliberal model 2 . 
The increase in homicide rates has been connected to social inequality, the rise in misery and poverty, the inefficiency of the legal system, growing impunity, spread of organized crime, governmental corruption, easy access to guns, and drug trafficking 67 . Land disputes for drugs trafficking and conflicts with the police favor the high number of homicides 51,61. Between 1991 and 2000, the proportion of homicides with firearms had a 50\% increase due to the use of guns trafficked by organized crime 29. Between 2000 and 2009, Brazil reduced the number of deaths from firearms after implementing the Disarmament Statute and national campaigns for voluntary firearm surrender in 2004 30. According to data from 2007, guns had been used in 71.5\% of deaths by homicide 29 .

\section{Other SDH}

Between 2000 and 2009, there was a significant decline in homicide rates in the state of São Paulo. A factor which could partly explain this decline, besides the aforementioned Disarmament Statute, is the rise in the arrestment of criminals 30,39,56, which theoretically caused a decline in homicides by preventing new homicides 7,30,39.

Despite corruption in politics also contributing to the number of homicides, as it foments the lack of confidence in government institutions 15 , there is a lack of rigorous studies addressing this issue.

Studies also mentioned other SDH that could be associated with homicides in Brazil. However, the quality of data produced for these other determinants was not relevant for this systematic review according to their quality assessment. Therefore, to avoid speculation, we have limited our discussion to the aforementioned SDH, despite being aware that they are not enough to thoroughly explore the subject.

\section{Protective factors}

One might consider these systematic review highlighted items as protective factors against homicide as they are present in lower homicide rate contexts. Some of these factors have already been discussed, such as economic equality, less social inequality and the improvement of social indicators 6,20,68. Differently from demographic density, which assesses the level of urbanization of a certain city, the average number of citizens per household defines family composition. In this sense, family composition seems to act as a protective factor against homicides in countryside cities, where the average number of people per household is higher 24 .

Regarding education, very few studies associate the people's education level with lower crime rates, although it has been noticed that higher education levels may significantly reduce homicide risk $18,30,38,62$. Considering this relation, it is possible to infer that education plays a major role in directly reducing homicide levels. Education can significantly reduce homicide risks, thus being an important protective factor 29,35,49,64. However, it is not possible to analyze an item in isolation from other SDH, since a lower level of education can be connected to a lower socioeconomic level, and thereby connected to a higher level of exposure to violence and homicides 6,24,30,48,57,60.

The Disarmament Statute possibly reduced the homicide rate for the white population, but for the black population, this rate increased, which suggests these efforts were less effective for the latter group 30. Therefore, race/ethnicity is able to predict part of the profile of homicide victims; the increase in inequalities shows how Brazilian public policies are only partially effective in controlling violence, not approaching specificities that characterize such a diverse population.

\section{Discussion}

This systematic review focused on the association between SDH and homicides in Brazil. The main determinants concerned territory; race/ethnicity; gender; age; social inequality and economic factors; development; education; work and employment; drugs and trafficking; among others. Intersection of these factors is quite present, sometimes hindering the development of a narrative synthesis of these categories individually. On the other hand, some protective factors against homicides have been 
found, such as higher levels of education and income, lower levels of social inequality, and recent public policies, such as the Disarmament Statute.

This review indicates that homicides are present in various macro and microregions of Brazil, despite not being evenly distributed. Homicides have been rising over the last years, both in capitals/ metropolitan areas and smaller cities 38. Regions undergoing anaccelerated urbanization process coupled with insufficient, unequal and reckless economic development seem to account for the largest portion of homicides 24,34,37,42,50. Assimilating territorial characteristics connected to the highest risks of homicides among specific groups (particularly men, young people, and black people) is a way of identifying the most vulnerable ones and developing targeted public policies 5 . We found a greater focus on the black population (the majority of victims), and a lack of studies on other ethnic minorities who also live under unequal conditions, such as indigenous people or immigrants. Understanding and making these information public alongside its territorial variations is challenging and a promising way of improving public health $16,26,55$.

Based on this systematic review, we believe it i paramount to reflect on the future of youth, particularly black youth, which frequently faces poverty, exclusion, and lack of opportunities and safety. In certain regions, this may lead young people, especially men, to turn themselves to crime as a profitable and economically attractive option 50 . Which would, lead to increased exposure to violence and even to homicides. Despite the number of studies on the association between poverty, inequity, and violence, its results do not always follow the same directions, presenting discordant conclusions 60 . A study carried out in Bahia 24 indicated how income or wealth alone is not enough to explain homicides. These data are important to prevent prejudiced associations between poverty, violence, and homicides. Some poorer Brazilian states, such as Piauí, have low homicide rates when compared to wealthy states, such as Paraná 21,30. Even in Paraná, wealthy regions such as the metropolitan area of Curitiba show higher homicide rates when compared to poorer areas of the same state $27,37,38$. There is need to interpret these data carefully to avoid associating homicide with income or poverty alone, also considering social inequality, which prevents people from certain opportunities. Intense exclusion seems to make individuals vulnerable, contributing to violence and homicides 6 .

These systematic reviews had many limitations, such as the diversity of methodologies employed by the eligible studies, as well as the quality and rigorousness of the accessed data, which made the conduction process quite challenging. This heterogeneity made it impossible for us to conduct a meta-analysis. The most critical limitation was that very few studies included nationwide or long time-series analyses. Most of them included local analysis and/or only approached a short time period. The CASP tool for critical appraisal was also a limitation. Space limitations also made the synthesis quite challenging, which might have left some information out. On the other hand, the methodological design proposed by the authors was a positive aspect that had been already previously established and that facilitated the systematic review conducting according to the PRISMA protocol.

We also detected some gaps in Brazilian research compared to an international study 71 on the same subject. The Brazil's legal context being one of them 2, mainly when it comes to the ineffiency of the penal system and its inability to solve this problem. Political factors, particularly corruption, impunity, and political intolerance (which consequently lead to a disbelief on the legitimacy of government and its institutions), are associated with the spread of homicides in other Latin American countries 2. Nevertheless, only a few studies $40,41,50$ drew a connection between homicides and the Brazilian political situation, the slowness of its legal system, the deterioration of public security, or the devaluation and corruption inside these institutions, besides the decline in their ethical values. All these topics would be paramount for new studies, considering its urgency for Brazilian contemporary society. 


\section{Contributors}

C. Wanzinack and M. C. Signorelli conceived the systematic review protocol, performed the article searches independently, tracked abstracts, read and assessed eligible studies; contributed to the narrative synthesis and wrote the text; revised and approved the final version of this article. C. Reis revised the protocol and acted as the third reviewer in case of disagreements; contributed to the narrative synthesis and wrote the text; revised and approved the final version of this article.

\section{Acknowledgments}

This study was financed in part by the Brazilian Graduate Studies Coordinating Board (Capes) Finance code 001, which granted the first author and the second author with scholarships for their Ph.D. and postdoctoral studies, respectively. The funder had no role in this systematic review.

\section{References}

1. World Health Organization. Global status report on violence prevention. Geneva: World Health Organization; 2014.

2. Franco S. A social-medical approach to violence in Colombia. Am J Public Health 2003; 93:2032-6.

3. De Jesus DE. Direito penal. São Paulo: Editora Saraiva; 1984.

4. Waiselfisz JJ. Mapa da violência 2012: os novos padrões da violência homicida no Brasil. São Paulo: Editora Sangari; 2012.

5. Duarte EC, Garcia LP, Freitas LRS, Mansano NH, Monteiro RA, Ramalho WM. Associação ecológica entre características dos municípios e o risco de homicídios em homens adultos de 20-39 anos de idade no Brasil, 1999-2010. Ciênc Saúde Coletiva 2012; 17:2259-68.

6. Gawryszewski VP, Costa LS. Homicídios e desigualdades sociais no Município de São Paulo. Rev Saúde Pública 2005; 39:191-7.

7. Nadanovsky P, Celeste RK, Wilson M, Daly M Homicide and impunity: an ecological analysis at state level in Brazil. Rev Saúde Pública 2009; 43:733-42.

8. Krug EG, Mercy JA, Dahlberg LL, Zwi AB. The world report on violence and health. Lancet 2002; 360:1083-8.

9. Sobral A, Freitas CM. Modelo de organização de indicadores para operacionalização dos determinantes socioambientais da saúde. Saúde Soc 2010; 19:35-47.

10. Krug EG, Dahlberg LL, Mercy JA, Zwi AB, Lozano R. Relatório mundial sobre violência e saúde. Genebra: Organização Mundial da Saúde; 2002.

11. Ayala Quintanilla BP, Taft A, McDonald S, Pollock W, Roque Henriquez JC. Social determinants and maternal exposure to intimate partner violence of obstetric patients with severe maternal morbidity in the intensive care unit: a systematic review protocol. BMJ Open 2016; 6:e013270.

12. Furuta M, Sandall J, Bick D. A systematic review of the relationship between severe maternal morbidity and post-traumatic stress disorder. BMC Pregnancy Childbirth 2012; 12:125.

13. Johnston R, Cahalan R, O'Keeffe M, O’Sullivan $\mathrm{K}$, Comyns $\mathrm{T}$. The associations between training load and baseline characteristics on musculoskeletal injury and pain in endurance sport populations: a systematic review. J Sci Med Sport 2018; 21:910-8.

14. Tacconelli E. Systematic reviews: CRD's guidance for undertaking reviews in health care. Lancet Infect Dis 2010; 10:226.

15. Salama P. Homicidios, ¿es ineluctable la violencia en América Latina? Frontera Norte 2013; 25:7-27.

16. Briceño-León R. La comprensión de los homicidios en América Latina: ¿Pobreza o institucionalidad? Ciênc Saúde Coletiva 2012; 17:3159-70. 
17. Briceño-León R, Villaveces A, Concha-Eastman A. Understanding the uneven distribution of the incidence of homicide in Latin America. Int J Epidemiol 2008; 37:751-7.

18. Phebo L, Moura AT. Urban violence: a challenge for pediatricians. J Pediatr (Rio J.) 2005; 81(5 Suppl):S189-96.

19. Haesbaert R. Territórios alternativos. São Paulo: Editora Contexto; 2002.

20. Perova E, Reynolds SA. Women's police stations and intimate partner violence: evidence from Brazil. Soc Sci Med 2017; 174:188-96.

21. Cerqueira D, Soares RR. The welfare cost of homicides in Brazil: accounting for heterogeneity in the willingness to pay for mortality reductions. Health Econ 2016; 25:259-76.

22. Garcia LP, Freitas LRS, Silva GDM, Höfelmann DA. Estimativas corrigidas de feminicídios no Brasil, 2009 a 2011. Rev Panam Salud Pública 2015; 37:251-7.

23. Molinatti F, Acosta LD. Trends in mortality by assault in women in selected countries of Latin America, 2001-2011. Rev Panam Salud Pública 2015; 37:279-86.

24. Sousa CAMDS, Cosme MFPD, Souza ERD. Determinants of homicides in the state of $\mathrm{Ba}$ hia, Brazil, in 2009. Rev Bras Epidemiol 2014; $17: 135-46$

25. Chiavegatto Filho ADP, Beltrán-Sánchez $H$, Kawachi I. Racial disparities in life expectancy in Brazil: challenges from a multiracial society. Am J Public Health 2014; 104:2156-62.

26. Gomez-Lievano A, Youn H, Bettencourt LM. The statistics of urban scaling and their connection to Zipf's law. PLoS One 2012; 7:e40393.

27. Andrade LD, Nihei OK, Pelloso SM, Carvalho MDB. Homicídios juvenis e informalidade em um município brasileiro da tríplice fronteira Brasil, Paraguai e Argentina. Rev Panam Salud Pública 2012; 31:380-7.

28. Meneghel SN, Hirakata VN. Femicídios: homicídios femininos no Brasil. Rev Saúde Pública 2011; 45:564-74.

29. Reichenheim ME, Souza ER, Moraes CL, Mello Jorge MHP, Silva CMFP, Minayo MCS. Violence and injuries in Brazil: the effect, progress made, and challenges ahead. Lancet 2011; 377:1962-75.

30. Soares Filho AM. Vitimização por homicídios segundo características de raça no Brasil. Rev Saúde Publica 2011; 45:745-55.

31. Cardona D, Peláez E, Aidar T, Ribotta B, Alvarez MF. Mortalidad por causas externas en tres ciudades latinoamericanas: Córdoba (Argentina), Campinas (Brasil) y Medellín (Colombia), 1980-2005. Rev Bras Estud Popul 2008; 25:335-52.

32. Cardoso FLMG, Cecchetto FR, Corrêa JS, Souza TO. Homicides in Rio de Janeiro, Brazil: an analysis of lethal violence. Ciênc Saúde Coletiva 2016; 21:1277-88.
33. Souza PF, Xavier DR, Rican S, Matos VP, Barcellos C. The expansion of the economic frontier and the diffusion of violence in the Amazon. Int J Environ Res Public Health 2015; 12:5862-85.

34. Barcellos C, Feitosa P, Damacena GN, Andreazzi MA. Highways and outposts: economic development and health threats in the central Brazilian Amazon region. Int J Health Geogr 2010; 9:30.

35. Sousa GDSD, Magalhães FB, Gama IDS, Lima MVND, Almeida RLFD, Vieira LJEDS, et al. Social determinants and their interference in homicide rates in a city in northeastern Brazil. Rev Bras Epidemiol 2014; 17:194-203.

36. Leites GT, Meneghel SN, Hirakata VN. Female homicide in Rio Grande do Sul, Brazil. Rev Bras Epidemiol 2014; 17:642-53.

37. Mansano NH, Gutierrez MM, Ramalho W, Duarte EC. Homicídios em homens jovens de 10 a 24 anos e condições sociais em municípios do Paraná e Santa Catarina, Brasil, 20012010. Epidemiol Serv Saúde 2013; 22:203-14.

38. Andrade SM, Soares DA, Souza RKT, Matsuo T, Souza HD. Homicides between men aged 15 to 29 years and related factors in the State of Paraná, Brazil, 2002/2004. Ciênc Saúde Coletiva $2011 ; 16: 1281-8$.

39. Nadanovsky P. O aumento no encarceramento e a redução nos homicídios em São Paulo, Brasil, entre 1996 e 2005. Cad Saúde Pública 2009; 25:1859-64.

40. Batista LE. Masculinidade, raça/cor e saúde. Ciênc Saúde Coletiva 2005; 10:71-80.

41. Lima MLC, Ximenes RAA, Souza ER, Luna CF, Albuquerque MFPM. Análise espacial dos determinantes socioeconômicos dos homicídios no Estado de Pernambuco. Rev Saúde Pública 2005 ; 39:176-82.

42. Trindade RFC, Costa FAMM, Silva PPAC, Caminiti GB, Santos CB. Map of homicides by firearms: profile of the victims and the assaults. Rev Esc Enferm USP 2015; 49:748-55.

43. Rojas Cabrera ES. Deaths from violent causes among adolescents and young adults in two cities of the Southern Cone: Córdoba (Argentina) and Porto Alegre (Brazil), 1990-2010. Ciênc Saúde Coletiva 2015; 20:29-37.

44. Santos SM, Barcellos C, Carvalho MS. Ecological analysis of the distribution and sociospatial context of homicides in Porto Alegre, Brazil. Health Place 2006; 12:38-47.

45. Pereira DV, Mota CM, Andresen MA. Social disorganization and homicide in Recife, Brazil. Int J Offender Ther Comp Criminol 2017; 61:1570-92.

46. Silva MA, Cabral Filho JE, Amorim MMR, Falbo Neto GH. Mulheres vítimas de homicídio em Recife, Pernambuco, Brasil, 2009/2010: um estudo descritivo. Cad Saúde Pública 2013; 29:391-6. 
47. Alves MMR, Alves SV, Antunes MBC, Santos DLP. External causes and maternal mortality: proposal for classification. Rev Saúde Pública 2013; 47:283-91.

48. Silva LS, Menezes MLN, Lopes CLA, Correa MSM. Anos potenciais de vida perdidos por mulheres vítimas de homicídio na cidade do Recife, Pernambuco, Brasil. Cad Saúde Pública 2011; 27:1721-30.

49. Santos SMD, Guimarães MJB, Araújo TVB. Desigualdades raciais na mortalidade de mulheres adultas no Recife, 2001 a 2003. Saúde Soc 2007; 16:87-102.

50. Tavares R, Catalan VDB, Romano PMM, Melo EM. Homicídios e vulnerabilidade social. Ciênc Saúde Coletiva 2016; 21:923-34.

51. Barcellos C, Zaluar A. Homicídios e disputas territoriais nas favelas do Rio de Janeiro. Rev Saúde Pública 2014; 48:94-102.

52. Araújo EMD, Araújo TMD, Santana F. Distribuição desigual da mortalidade por causas externas: avaliação de aspectos socioeconômicos. Rev Baiana Saúde Pública 2014; 29:262-72.

53. Chiavegatto Filho ADP, Gotlieb SLD, Kawachi I. Cause-specific mortality and income inequality in São Paulo, Brazil. Rev Saúde Pública 2012; 46:712-8.

54. Peres MFT, Almeida JF, Vicentin D, Ruotti C, Nery MB, Cerda M, et al. Evolução dos homicídios e indicadores de segurança pública no Município de São Paulo entre 1996 a 2008: um estudo ecológico de séries temporais. Ciênc Saúde Coletiva 2012; 17:3249-57.

55. Nery MB, Peres MFT, Cardia N, Vicentin D, Adorno S. Regimes espaciais: dinâmica dos homicídios dolosos na cidade de São Paulo entre 2000 e 2008. Rev Panam Salud Pública 2012; 32:405-12.

56. Peres MFT, Vicentin D, Nery MB, Lima RS, Souza ER, Cerda M, et al. Queda dos homicídios em São Paulo, Brasil: uma análise descritiva. Rev Panam Salud Pública 2011; 29:17-26.

57. Peres MF, Almeida JF, Vicentin D, Cerda M, Cardia N, Adorno S. Fall in homicides in the city of São Paulo: an exploratory analysis of possible determinants. Rev Bras Epidemiol 2011; 14:709-21.

58. Lotufo PA, Benseñor IM. Income inequality and male homicide rates: São Paulo, Brazil, 1996-2007. Eur J Public Health 2009; 19:602-4.

59. Barata RB, Ribeiro MCSA, Sordi M. Desigualdades sociais e homicídios na cidade de São Paulo, 1998. Rev Bras Epidemiol 2008; 11:3-13.

60. Peres MFT, Cardia N, Mesquita Neto P, Santos PCS, Adorno S. Homicídios, desenvolvimento socioeconômico e violência policial no Município de São Paulo, Brasil. Rev Panam Salud Pública 2008; 23:268-76.

61. Kilsztajn S, Carmo MSN, Sugahara GTL, Lopes ES. Vítimas da cor: homicídios na região metropolitana de São Paulo, Brasil, 2000. Cad Saúde Pública 2005; 21:1408-15.
62. Minayo MCS, Constantino P. An ecosysthemic vision of homicide. Ciênc Saúde Coletiva 2012; 17:3269-78.

63. Viana LAC, Costa MCN, Paim JS, Vieira-daSilva LM. Social inequalities and the rise in violent deaths in Salvador, Bahia State, Brazil: 2000-2006. Cad Saúde Pública 2011; 27 Suppl 2:S298-308.

64. Araújo EM, Costa MCN, Hogan VK, Mota ELA, Oliveira NF, Araujo TM. Diferenciais de raça/cor da pele em anos potenciais de vida perdidos por causas externas. Rev Saúde Pública 2009; 43:405-12.

65. Bastos MJRP, Pereira JA, Smarzaro DC, Costa EF, Bossanel RCL, Oliosa DMS, et al. Análise ecológica dos acidentes e da violência letal em Vitória, ES. Rev Saúde Pública 2009; 43:12332.

66. Minamisava R, Nouer SS, Morais Neto OL, Melo LK, Andrade ALSS. Spatial clusters of violent deaths in a newly urbanized region of Brazil: highlighting the social disparities. Int J Health Geogr 2009; 8:66.

67. Caiaffa WT, Almeida MC, Oliveira CD, Friche AA, Matos SG, Dias MA, et al. The urban environment from the health perspective: the case of Belo Horizonte, Minas Gerais, Brazil. Cad Saúde Pública 2005; 21:958-67.

68. Nadanovsky P, Cunha-Cruz J. The relative contribution of income inequality and imprisonment to the variation in homicide rates among Developed (OECD), South and Central American countries. Soc Sci Med 2009; 69:1343-50.

69. Belon AP, Barros MB, Marín-León L. Mortality among adults: gender and socioeconomic differences in a Brazilian city. BMC Public Health 2012; 12:39.

70. Souza TOD, Pinto LW, Souza ER. Estudo espacial da mortalidade por homicídio, Bahia, 1996-2010. Rev Saúde Pública 2014; 48:468-77.

71. Cole JH, Gramajo AM. Homicide rates in a cross-section of countries: evidence and interpretations. Popul Dev Rev 2009; 35:749-76.

72. Bando DH, Lester D. An ecological study on suicide and homicide in Brazil. Ciênc Saúde Coletiva 2014; 19:1179-89.

73. Araújo EMD, Costa MCN, Oliveira NF, Santana FS, Barreto ML, Hogan V, et al. Spatial distribution of mortality by homicide and social inequalities according to race/skin color in an intra-urban Brazilian space. Rev Bras Epidemiol 2010; 13:549-60. 


\section{Resumo}

O Brasil tem atualmente o maior número absoluto de homicídios do mundo, resultado de uma série de fatores complexos. O estudo teve como objetivo compreender as associações entre os determinantes socioambientais da saúde (DSS) e os homicídios no Brasil através de uma revisão sistemática da literatura. A revisão seguiu as normas PRISMA, selecionando estudos quantitativos e qualitativos publicados em português, inglês e espanhol e realizados entre 2002 e 2017, disponiveis nas bases de dados PubMed, MEDLINE, LILACS, SciELO e BVS-BIREME. Dois revisores trilingues rastrearam os estudos de maneira independente com base nos critérios de elegibilidade. Avaliamos criticamente os estudos selecionados com o Critical Appraisal Skills Programme (CASP) ou a Checklist for Analytical Cross-Sectional Studies, a depender do delineamento do estudo. Analisamos 60 estudos e agrupamos seus DSS em categorias para elaborar uma narrativa-sintese sobre cada DSS. Essas categorias foram: território; raçal cor; gênero; idade; desigualdades sociais e fatores econômicos; desenvolvimento; educação; trabalho e emprego; drogas e tráfico e outros DSS. Alguns DSS estiveram mais fortemente associados aos homicídios, tais como: idade mais jovem, raça negra, sexo masculino, escolaridade baixa e residência em área de maior desigualdade social, como periferias urbanas e fronteiras agrícolas. Destacaram-se também o desemprego e o tráfico de drogas, além de interações entre diversos DSS. A educação parece ser um fator de proteção contra o homicídio. Apesar da capacidade de interpretação limitada, devido à ampla gama de abordagens metodológicas, a revisão mostra a importância de considerar os DSS e suas interações no desenvolvimento de políticas de prevenção do homicídio.

Homicídio; Violência; Determinantes Sociais da Saúde

\section{Resumen}

Brasil cuenta actualmente con el mayor número absoluto de homicidios del mundo, resultado de una serie de factores complejos. El objetivo del estudio fue comprender las asociaciones entre los determinantes socioambientales de salud (DSS) y los homicidios en Brasil, a través de una revisión sistemática de la literatura. La revisión siguió las normas de PRISMA, seleccionando estudios cuantitativos y cualitativos, publicados en portugués, inglés y español, y realizados entre 2002 y 2017, disponibles en las bases de datos PubMed, MEDLINE, LILACS, SciELO y BVS-BIREME. Dos revisores trilingües rastrearon los estudios de manera independiente, en base a criterios de elegibilidad. Evaluamos críticamente los estudios seleccionados con el Critical Appraisal Skills Programme (CASP) o la Checklist for Analytical CrossSectional Studies, dependiendo de la tendencia del estudio. Analizamos 60 estudios y agrupamos sus DSS en categorías para elaborar una sintesis narrativa sobre cada DSS. Esas categorías fueron: territorio; raza/color; género; edad; desigualdades sociales y factores económicos; desarrollo; educación; trabajo y empleo; drogas y tráfico y otros DSS. Algunos DSS estuvieron más fuertemente asociados a los homicidios, tales como: edad más joven, raza negra, sexo masculino, escolaridad baja y residencia en un área de mayor desigualdad social, como periferias urbanas y fronteras agrícolas. Se destacaron también el desempleo y el tráfico de drogas, además de interacciones entre diversos DSS. La educación parece ser un factor de protección contra el homicidio. A pesar de la capacidad de interpretación limitada, debido a una amplia gama de enfoques metodológicos, la revisión muestra la importancia de considerar los DSS $y$ sus interacciones en el desarrollo de politicas de prevención de homicidios.

Homicidio; Violencia; Determinantes Sociales de la Salud
Submitted on $23 / \mathrm{Jan} / 2018$

Final version resubmitted on 05/Aug/2018

Approved on 31/Aug/2018 